\title{
Islamic Humanity: A New Approach to Minimizing Non-Performing Financing at the Islamic Bank in Indonesia
}

\author{
Ahmad ROZIQ ${ }^{1}$, Faqih Ulil ABSHOR ${ }^{2}$, Agung Budi SULISTIYO ${ }^{3}$, Sumani SUMANI ${ }^{4}$
}

Received: August 01, 2020 Revised: October 26, 2020 Accepted: November 16, 2020

\begin{abstract}
NPF Islamic banking needs to be resolved because it affects banking performance in terms of income and the quality of its productive assets. This study aims to solve problems of non-performing financing and assess and analyze whether the implementation of the Islamic Humanity model can reduce the problem of financing at Bank Syariah Mandiri Indonesia. The study uses qualitative method with Miles and Huberman approach for analizing data through four steps which are; (a) data collection (b) data reduction (c) data display, and (d) conclusion drawing/ verification. The results of the study found non performing financing can be reduced with using a new approach namely the Islamic Humanity Approach, which is an interaction between several aspects, namely (a) spiritual aspects, (b) economic aspects, (c) social aspects, and (d) justice aspects. The Islamic humanity model carried out in problem-solving activities at Bank Syariah Mandiri Indonesia includes a friendly approach, communication and deliberation in a family, respect for people, empathy, the concept of justice, and the concept of prayer. Islamic humanity approach shows success in reducing non-performing financing. The research concluded Islamic humanity as a new approach to reduce non-performing financing at Bank Syariah Mandiri Indonesia and it can be implemented to all Islamic banking in Indonesia.
\end{abstract}

Keywords: Sharia, Economic Justice, Islamic Banking, Islamic Humanity, Non-Performing Financing

JEL Classification Code: E58, G24, G21, G23, G41

\section{Introduction}

The concept of Islam and humanity must go hand in hand so that the Islamic sharia that is implemented in Indonesia is a friendly, open, and practices inclusive Islam. If the values of Islam and humanity are in harmony and the breath of the souls of Muslims in Indonesia, Islamic sharia in Indonesia will be able to provide solutions to

${ }^{1}$ First Author and Corresponding Author. Associate Professor, Faculty of Economics and Business, University of Jember, East Java, Indonesia [Postal Address: Jl. Kalimantan No.37, Krajan Timur, Sumbersari, Kec. Sumbersari, Kabupaten Jember, Jawa Timur 68121, Indonesia] Email: ahmadroziq.feb@unej.ac.id

2Lecturer, Bank Syariah Mandiri, Indonesia. Email: faqihulil@gmail.com

${ }^{3}$ Assistant Professor, Faculty of Economics and Business, Andalas University, Padang, West Sumatra, Indonesia.

Email: Agungbudi.feb@unej.ac.id

${ }^{4}$ Associate Professor, Faculty of Economics and Business, University of Jember, East Java, Indonesia. Email: sumani@unej.ac.id

(c) Copyright: The Author(s)

This is an Open Access article distributed under the terms of the Creative Commons Attribution Non-Commercial License (https://creativecommons.org/licenses/by-nc/4.0/) which permits unrestricted non-commercial use, distribution, and reproduction in any medium, provided the original work is properly cited. various major problems of the nation, including economic problems (Maarif, 2009). By what is mentioned in the Holy Quran, the values of humanity in Islam (Islamic humanity) highly upholds the values of justice, truth, benefit, and rahmatan lil 'alamin. Islamic economists agree that the Islamic economy must apply universal principles concerning the issue of the rights and relationships of individuals with society (Antonio, 2017). These principles include: First, the interests of the wider community must take precedence over individual interests. Second, letting go of other people's difficulties must be prioritized over giving benefits or benefits, even though both are equally sharia objectives. Third, greater losses cannot be accepted to eliminate smaller losses. Therefore, finding a solution of problematic financing must still be based on sharia and humanitarian principles.

Bank's efficiency may also be related to the level of NPF. However, Firmansyah (2014) stated that there was no effect on the NPF level's level of efficiency. Zaini and Karim, Chan, and Hassan (2010), Berger and DeYoung (1997), Espinoza and Prasad (2010), and (Hosen \& Muhari, 2019) concluded that the lower level of efficiency could escalate the level of NPF. Consequently, the level 
of cost efficiency is an important indicator of bad quality loans. The study from Berger and DeYoung (1997) and Zaini Abd Karim, Chan, and Hassan (2010) proved that bad quality of management could escalate bad quality loans. Meanwhile, Espinoza and Prasad (2010) expressed the belief that banks' higher profitability described better managed banks, which contributed to minimizing the NPF level.

Fauzi (2012) states that in carrying out its business activities, Islamic banks must be by maqashid al-shariah (sharia objectives), namely for the good and welfare of humanity. Islamic banks must play an active role in improving the welfare of humanity and the environment, not just fighting for an economy free from usury (Fauzi, 2012). As Islamic banking's growth is growing rapidly from year to year, one of the problems faced in the world of Islamic banking is how to cope with Non-Performing Financing (NPF). NPF is a percentage of the amount of non-performing financing to the total financing issued by banks. Based on Islamic banking statistics published by the Financial Services Authority (OJK), NPF of Islamic banking can be seen that NPF (gross) of Islamic banking at the end of December 2015 to 2018 amounted to $3.98 \%, 3.50 \%, 3.57 \%$ and $2.34 \%$ respectively which is still within safe limits as according to the Central Bank regulations, Islamic banking is said to be healthy if the NPF is below 5\%. NPF settlement is needed in a good and in a fair manner for all parties. From NPF Islamic banking, it needs to be resolved because it affects banking performance in terms of income and the quality of its productive assets. In terms of revenue, the NPF will erode bank profits and increase reserve costs. For saving Customers, it will reduce the share of revenue obtained, while from a national point of view, it will reduce the contribution to the development and economic growth of a country. Therefore, an in-depth approach and analysis are needed to solve the problem. Many factors that cause the occurrence of problematic financing in Islamic Banks, the factors causing this problematic financing are due to the character of the Customer, the ratio of capital (capital) to debt (leverage), as well as general economic conditions such as rising prices of goods and declining purchasing power of the society.

Following the progress of handling financial problems in Bank Syariah Mandiri Indonesia, we illustrate the following:

Based on the above table, the Islamic Bank NPF number at the beginning of 2016 was very high at $9.73 \%$. According to Bank Indonesia, this figure exceeds the safe limit of sound banking criteria, which is $5 \%$. During 2016 that number could be reduced to $2.59 \%$ by the end of the year. This significant decrease shows that the NPF handling program launched by Syariah Bank is running successfully. Based on the background described above,
Table 1: Progress in Handling NPF Bank Syariah Mandiri Indonesia

\begin{tabular}{|l|l|c|}
\hline No & \multicolumn{1}{|c|}{ Month } & \% NPF \\
\hline 1 & January & $9,73 \%$ \\
\hline 2 & February & $10,36 \%$ \\
\hline 3 & March & $8,61 \%$ \\
\hline 4 & April & $8,45 \%$ \\
\hline 5 & May & $8,04 \%$ \\
\hline 6 & June & $7,95 \%$ \\
\hline 7 & July & $7,80 \%$ \\
\hline 8 & August & $7,41 \%$ \\
\hline 9 & September & $6,67 \%$ \\
\hline 10 & October & $4,51 \%$ \\
\hline 11 & November & $2,56 \%$ \\
\hline 12 & December & $2,59 \%$ \\
\hline
\end{tabular}

Source: Bank Syariah Mandiri Indonesia

the authors are interested in researching the problem financing handling at Bank Syariah Mandiri Indonesia. Researchers want to study and analyze what approaches have been taken by the management of an independent Islamic bank. This study's results are expected to provide an overview of key factors or benchmarking in minimizing NPF and improving the quality of financing in all Islamic banks in Indonesia.

Several studies on financial problems in Islamic banking has been done including by Nurjanah and Hilyatin (2016) study on the rescue of problem financing in Murabaha financing in Bank Syariah Mandiri Purwokerto Branch, this study uses two strategies to overcome problem financing: stay strategy and the exit strategy.

Jureid's (2016) concludes that Bank Muamalat Panyabungan carries out risk management by carrying out the Financing Risk Assessment (FRA) process on several aspects of the financing process and then continues with intensive billing, provides reprimands, revitalization processes (rescheduling, reconditioning, restructuring), a settlement with guarantees, litigations, and conduct monitoring and controlling. African and Maesyaroh (2017) research concerning efforts to handle problem financing at PT. BPRS Margarizki Bahagia is carried out with the principle of a win-win solution and a familial approach in a bottom-up process; (d) Ibrahim and Rahmati's research (2017) found that the problem-solving policies on BMI were carried out through OTS, billing, subpoena, restructuring, collateral sales, writing off and establishing fines and establishing a special team to handle problematic financing. 
This research is a development research which has been taken from the researches done by the previous researchers namely Nurjanah and Hilyatin (2016); Africa and Maesyaroh (2017); Ibrahim and Rahmati (2017) and applied research of Rasulullah's educational values namely: the values of equality, solidarity, justice and virtue that have been examined by Robingun (2014). The difference between this research and some previous studies is that if the previous study used various banking policies and regulations as a reference in the discussion, in this study the researcher wanted to look for the key factors and alternative methods which were improvised techniques for handling problem financing by Bank Syariah Mandiri Indonesia. Researchers want to study and determine the methods or techniques used in addition to conventional methods that already exist. By the research subject, namely Islamic banking, the researcher wants to examine the involvement of humanitarian and Islamic concepts in the activity, where the results are expected to be different from the method or methods that have been carried out by other banking institutions, especially conventional banking. So the results of this study are expected to provide new treasures, especially in the development of Islamic banking. Based on the explanation above, the purpose of this study is to: (a) solve and assess problems related to non-performing financing and (b) analyze the application of the Islamic Humanity model, whether it can reduce financing at Bank Syariah Mandiri Indonesia.

\section{Literature Review}

\subsection{Humanity According to Islam}

According to Robingun (2016), humanism in Islam is humanizing humans according to their role as caliphs on earth. Humanism in Islam is a religious concept that places man as a human being by taking into account the responsibility of the human relationship with God and between humans and humans. Islamic humanism, according to Kuntowijoyo (1993), is theocentric, which means that humans must continue to focus on God, but the goal remains for humans themselves. Religious beliefs rooted in theocentric views are always associated with the deeds of human beings themselves in the Islamic religion integrated into faith, Islam, and ihsan. So that on an individual scale, humans can achieve something to the maximum degrees with a variety of potentials it has.

According to (Shadily, 1983; Robingun, 2016), humanism is a view of life that aims to understand humanity and humanity as the basis and purpose of all thoughts, science, culture, and religion. Humanism is also interpreted as a belief system that focuses on human needs and seeks ways to solve human problems based more on reason than faith in God. A review of the philosophy of humanism is interpreted as a philosophy that states the main purpose it has for the safety and welfare of humanity (Shari'ati, 1995). Humanism can be understood as a view that makes humans the center of attention, in the understanding of humans, humans, and humans (Robingun, 2016). The view of humanism states that humans are the measure of all things, the center of significance, and the container of all virtues. Tuasikal (2009) classifies a number of Islamic principles and attitudes about how a Muslim should act in a debt-debt relationship, which are as follows: (a) the virtue of the person giving the debt ((HR. Muslim no. 2699), (b) claiming debt in a way that Both (HR. Bukhari no. 2076) (HR. Ibn Majah no. 1965) and (HR. Ibn Majah no. 1966), (c) give a time out for people with difficulties (QS. Al Baqarah: 280) (HR. Muslim no. 3006) (HR. Ahmad, Abu Ya'la, Ibn Majah, Ath Thobroniy, Al-Hakim, Al Baihaqi.) Moreover, (d) give ease to people who will pay off their debts (HR. Ahmad).

\subsection{Financing under Islamic Law}

The capital-profitability relationship has been explained by a variety of breakthrough theories. Initially, (Dao and Nguyen 2020; Modigliani and Miller, 1958) discovered the capital structure irrelevance theory, in which firm value is unaffected by its capital structure in the light of perfect capital market. In particular, under the assumptions of a perfect capital market, bankruptcy cost, taxation, barriers to entry and deposit insurance do not exist. Besides, all relevant information is publicized, bank management no longer owns private information, leading to the situation that both creditors and shareholders are symmetrically informed of bank investment payoffs. Under these circumstances, it is proved that optimal debt to equity no longer exists and capital structure is irrelevant to equity holders' wealth. Thus, management can randomly select the composition of capital structure.

In-Law No. 21 of 2008 concerning the Islamic Banking, it is stated that financing is the provision of funds in the form of profit-sharing transactions in the form of mudharaba and musyarakah, leasing transactions in the form of ijara or leasing in the form of ijara muntahiya bittamlik, sale and purchase transactions in the form of murabahah receivables, greetings, and istishna, lending and borrowing transactions in the form of qardh receivables, as well as leasing transactions in the form of ijara, based on an agreement or agreement between a Islamic bank and another party that requires a party financed or given fund facilities to return the funds after a certain period with rewards in the form of ujrah, without rewards, or profit-sharing. Financing has several functions that are very diverse, because the existence of Islamic banks that run financing based on sharia principles is not only to seek profits and enliven the banking business in Indonesia (Karim, 2010), but also to create a safe, fair business environment according to Islamic law including (a) providing financing with sharia principles that apply a profitsharing system that does not burden the debtor; (b) helping the poor who are not touched by conventional banks because they are unable to meet the requirements set by conventional banks; and (c) helping the weak economic community which is always 
being played by moneylenders by helping through funding for the business done.

\subsection{Problematic Financing and Its Causes}

Based on Bank Indonesia Regulation Number: 7/2/ PBI / 2005 Article 12 paragraph 3 the quality of Customer financing is classified into five categories, namely: (1) collectability (smooth financing: payment of principal installments or interest on time); (2) collectibility (financing special attention: there are arrears in principal installments and/or margins that have not exceeded 90 days); (3) collectible (underdone financing: there are arrears in principal installments and/or margins that have exceeded 90 days) (91 to 120 days); (4) collectibility (financing is doubtful: there are arrears in principal installments and/or margins that have exceeded 180 days); and (5) collectibility (non-performing financing: there are arrears in principal installments and/or margins that have exceeded 180 days).

A non-performing loan is a condition where customers can no longer afford repayments to banks according to the provisions of Bank Indonesia Regulation No.7 / 2 / PBI / 2005. Non-performing loans to banks are situations where customers can no longer pay part or all of their obligations following the deed of an agreement made with the bank (Harianto 2017; Louzis, Vouldis, and Metaxas 2012; Messai and Jouini 2013). Non-performing loans can generally be classified into several levels of collectability, namely, substandard, doubtful, and loss (Saba, Kouser, \& Azeem, 2012). Non-Performing Loans are an indication that there are problems in the bank, which, if not immediately followed up, will harm the bank. One of the adverse effects that impacts the bank is that the owned capital will decrease. The problematic credit factor can be seen from various aspects, including the Customer side (Kencana, Hariyani, \& Panjaitan, 2016), management factor (Haneef, Rana, and Karim 2012), operational factor (Adeyemi 2011), as well as external sides such as economic conditions and the condition of the bank itself (Abid, Ouertani, and ZounariGhorbel 2014).

The most significant risk of non-performing loans in banks is that it will also influence the value of the assets of the bank itself. Therefore, the profitability of a bank is the most critical measurement of the performance of a bank. Return on Assets focuses on the ability of a bank to benefit from its operations through its active capabilities. The higher the value of the non-performing loans or bad loans, the more it will affect the decline in profits/profits of a bank due to poor credit quality (Burton, Lauridsen, and Obel 2002; Selling and Stickney 1989; Tangngisalu et al. 2020). Return on Assets is one of the basic measures to assess a company's profitability (Muhammad, Rehman, and Waqas, 2016; Qayyum and Noreen, 2019; Yanikkaya, Gümüş, and Pabuçcu, 2018)

According to Firdaus and Ariyanti (2008), in general, the factors that cause problematic financing are (a) factors of the debtor (the character of the debtor's Customer and the ratio of capital to debt); (b) internal factors of financing. According to Siswanto (2009) internal factors include: (a) an assessment or collateral assessment that is higher than the actual value; (b) inexperienced business customers; (c) banks rarely conduct cash flow analysis and the ability to repay debtors; (d) there is no attempt by banks to supervise the use of financing; (e) the top leadership of a bank is too dominant in the decision making process for financing; (f) the bank does not pay attention to reports from third parties that do not favor debtors; and (g) banks fail to control collateral as soon as they see signs that the financing provided is developing towards non-performing financing. Non-performing financing (NPF) is a measure of the risks of financing disbursed to the third parties on the basis of profit sharing and margin principles. The risks here are the risks arising from the repayment of financing principal and rate of profit-sharing or margin. Risk of the repayment could be caused by internal and external matters (Waemustafa \& Sukri, 2015; Jusni et al, 2019). In the internal issue, NPF possibly increases when a bank faces competitive condition (Masruki et al., 2014), moral hazard problem (Samad \& Hasan, 1999), expansion of financing policies (Poetry \& Sanrego, 2014) and downturn in economic condition (Havidz \& Setiawan, 2015; Nasih, 2014).

\section{Research Methodology}

The research uses a case study approach. This research seeks to explore and analyze the steps taken in an effort to handle problem financing at Bank Shariah Mandarin (BSM) Indonesia. The type of data in this study are primary data in the form of opinions, perceptions of action and experience and secondary data in the form of financial reports and supporting data. Data collection techniques were carried out by observation, interview and documentation. The purpose of the combination of the three methods is so that the data or information obtained can complement each other (Fatchan, 2011). In addition to the method, the researcher also adopted the Imam Bukhari methodology with several criteria of the resource persons, namely (a) tsiqah (trustworthy and trustworthy), (b) having experienced / been involved or had met people who experienced / were involved in events that were the object of research, (c) credible (Az-Zahrani, 2017). The data analysis stage is the stage for systematically collecting and organizing notes of observations, interviews, and documentation. The data analysis technique used in this study is to follow the concept given by Miles and Huberman (2014). The steps undertaken in the data analysis process is as follows: (a) data collection, (b) data reduction, (c) data presentation, and (d) drawing conclusions / verification. Miles and Huberman's (2014) data analysis techniques can be seen in Figure 1. 


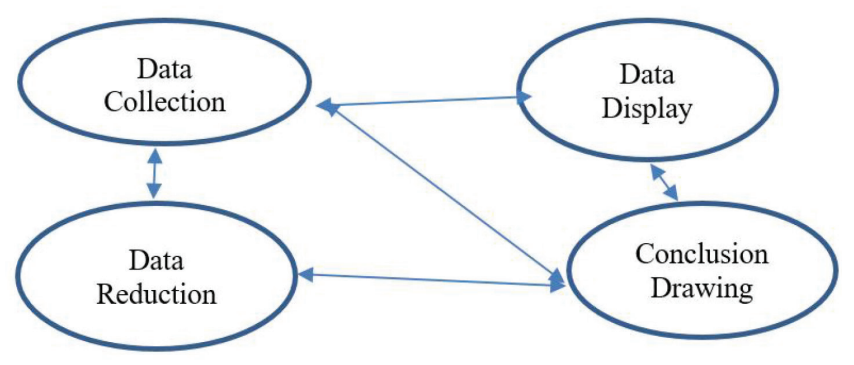

Figure 1: Steps of Interactive Data Analysis (Miles \& Huberman:2014)

Along with data analysis, data validity testing is needed, which consists of (Sugiyono, 2014); (a) testing the credibility of the data; (b) transferability testing; (c) dependability testing; and (d) confirmability testing.

\section{Results}

Based on interviews and documentation of researchers, financing products distributed by branches under Bank Syariah Mandiri Indonesia are: (a) working capital financing for the business banking segment; (b) working capital financing in the micro-segment; (c) financing BSM equipment; (d) BSM pensioner financing; (e) BSM OTO financing; (f) pilgrimage bailout financing; and (g) financing BSM gold pawning. This financing is what generates the principal income for BSM. However, if it is mismanaged, it will lead to non-performing financing which results in BSM Indonesia experiencing losses and even bankruptcy. Based on the results of interviews, documentation, and observations made by researchers, several steps can be summarized by BSM Indonesia in the settlement of problem financing activities. The stages of solving problematic financing at BSM Indonesia can be presented through the table below.

Based on the analysis of researchers and the literacy study conducted, the Islamic Humanity approach in handling problem financing in Indonesia can be described as follows:

a) Communication with a humanitarian approach. Humanitarian aspects in solving problematic financing at BSM Indonesia, can be seen from the communication approach and offering a good and fair settlement for both parties.

b) Patience and empathy. Success in the billing process requires an efficient communication approach and high patience and empathy for customers.
Table 2: Stage of Handling Problematic Financing at BSM Indonesia

\begin{tabular}{|l|l|l|}
\hline No & \multicolumn{1}{|c|}{ Stage } & \multicolumn{1}{c|}{ Information } \\
\hline 1 & Regular Collection & $\begin{array}{l}\text { Billing is done by calling } \\
\text { customers, and visiting } \\
\text { customers directly } \\
\text { (friendship) }\end{array}$ \\
\hline 2 & Restructuration & $\begin{array}{l}\text { Make changes to the } \\
\text { financing scheme, both } \\
\text { changes in the period, } \\
\text { changes in the number of } \\
\text { payments and the number of } \\
\text { installments }\end{array}$ \\
\hline 3 & $\begin{array}{l}\text { Repayment with } \\
\text { Margin Discount }\end{array}$ & $\begin{array}{l}\text { Providing relief for customers } \\
\text { who want to pay off by } \\
\text { giving margin cuts and or } \\
\text { eliminating fines }\end{array}$ \\
\hline 4 & $\begin{array}{l}\text { Guaranteed Goods } \\
\text { Auction }\end{array}$ & $\begin{array}{l}\text { Conduct an auction for } \\
\text { collateral submitted by the } \\
\text { Customer }\end{array}$ \\
\hline
\end{tabular}

Source: BSM Indonesia

The bank must focus on two things, namely whether the relationship with the Customer will be continued or resolved immediately. The policy is known as the concept of stay strategy and exit strategy.

c) The concept of hospitality and prayer. Other Islamic values that are applied in the process of solving problematic financing are friendship and prayer. One of the supporting factors for success in collecting hajj customers is by diligence in offering hospitality. In the Morning Prayer ritual at an independent Islamic bank, in addition to praying for the interests of the world, care always prayed for so that the business always remains smooth and blessed. (QS. Ghafir: 60, Al-Baqarah: 186 and HR. Ahmad 3/18)

d) Concept of justice. The concept of fairness in handling problematic financing is by applying the settlement method in accordance with the conditions/ types of customers. One of the methods of handling it is that the bank must be able to classify the condition/ character of the Customer so that the settlement method can be properly determined. The condition of problem customers is broken down into four types of customers.

The following table can illustrate the classification of problem customers and how to handle them. 
Table 3: Classification of customers and Methods of Handling Problematic Financing at BSM Indonesia

\begin{tabular}{|c|c|c|}
\hline No & $\begin{array}{l}\text { Type of } \\
\text { Customer }\end{array}$ & Information \\
\hline 1 & $\begin{array}{l}\text { Orderly } \\
\text { Customer } \\
\text { (capable and } \\
\text { fluent) }\end{array}$ & $\begin{array}{l}\text { Customers can pay and are } \\
\text { consistent in payments. For this type } \\
\text { of , Customers, the banks practice the } \\
\text { concept of hospitality and maintain } \\
\text { good relations with Customers. }\end{array}$ \\
\hline 2 & $\begin{array}{l}\text { Customer } \\
\text { Disorder } \\
\text { (able to pay } \\
\text { but often } \\
\text { late) }\end{array}$ & $\begin{array}{l}\text { Customers can pay but are often } \\
\text { late in payment. For this type of } \\
\text { Customers, the banks practice the } \\
\text { concept of hospitality and maintain } \\
\text { good relations with Customers. }\end{array}$ \\
\hline 3 & $\begin{array}{l}\text { Disorderly } \\
\text { Customer } \\
\text { (lazy/ } \\
\text { reluctant to } \\
\text { pay) }\end{array}$ & $\begin{array}{l}\text { Customers can pay but are lazy/ } \\
\text { reluctant to pay. For this type of } \\
\text { Customers, the bank practices the } \\
\text { concept of friendship and intensive } \\
\text { billing both by telephone and by } \\
\text { physical visits. If there is still no good } \\
\text { faith from the Customer, the bank } \\
\text { will ask the Customer to pay off, sell } \\
\text { collateral, and finally the collateral } \\
\text { auction if the Customer does not } \\
\text { settle his obligations }\end{array}$ \\
\hline 4 & $\begin{array}{l}\text { Customer } \\
\text { cannot pay }\end{array}$ & $\begin{array}{l}\text { It is a condition in which a Customer } \\
\text { does not have the financial capacity } \\
\text { to make payments. For this type } \\
\text { of Customer, the bank carries out } \\
\text { the concept of friendship, family } \\
\text { communication, and deliberation to } \\
\text { get a solution that does not harm both } \\
\text { the parties. Usually, the follow-up } \\
\text { to this process is the completion of } \\
\text { the restructuring, a settlement with } \\
\text { marginal discounts, and voluntary } \\
\text { sale of collateral. }\end{array}$ \\
\hline
\end{tabular}

\section{Discussion}

Based on the research results and discussions above, the concept of Islamic Humanity in solving problematic financing which has been found by the researchers while researching BSM Indonesia can be presented through the following table.

Based on the data analysis results, we can create a model for handling problematic financing with the Islamic Humanity approach, which is also a development of the Eko (2010) sustainability model. Researchers include aspects of spirituality and justice aspects are also additional aspects found by the author during the research.

The above model can describe the handling of problem financing using the concept of Islamic Humanity which is the interaction between several aspects, namely (a) the spiritual aspect, is the most important aspect where every action, action, and policy in Islamic banks must be based on Islamic sharia; (a) economic aspects, directly related to profit, the company must still be oriented to seeking profit; (c) social aspects, related to human welfare both internal company parties such as employees or customers and other parties associated with the bank; (d) justice aspect, Islamic banks handle financing in accordance with the conditions/character of the Customer. Every step taken by the bank will always pay attention to justice so that no party is harmed/wronged.

The concept of handling problematic financing at BSM Indonesia using conventional methods is compared to accounting information-based approaches and Islamic humanity. The initial condition is a situation where the NPF rate is still very high, at $9.73 \%$. This condition is the background for BSM Indonesia to carry out various procedures and policies to reduce it. Researchers identified the strategies used by banks so far, namely, conventional procedures. Billing is done in the usual way in accordance with banking regulations, namely regular collections, where the process of handling problem financing begins with billing either by calling the Customer or visiting the Customer. If the process has been carried out and the Customer has not paid, it will proceed with the issuance of Notification of Arrears. The bank will then issue a Warning Letter I and Warning Letter II, for cooperative customers, the bank will offer restructuring offers and repayment options. If the Customer has not paid the arrears, the next process is the Issuance of Warning Letter III and continued with the guarantee auction process. The next step is to improve the internal strategy in handling NPF, namely by including accounting information as a basis in each stage of making a problematic financing policy settlement (according to Figure 3).

After the internal strategy has been improved, the next stage is the improvement of the external strategy, namely the improvement of the billing approach with the concept of Islamic humanity. The key to this step is the billing process with an approach that prioritizes communication and consultation with the Customer, and the bank will provide a settlement offer that is by the Customer's condition so that it does not harm both the parties. Usually, the Customer will file a restructuring before the Warning Letter is issued from the bank. Furthermore, if the condition of the Customer does not allow restructuring, then an exit strategy will be carried out, namely repayment with margin discounts or collateral sales voluntarily. The result of this approach is the settlement of problem financing in a way that is solutive for all parties, and the Customer can settle his obligations without having to do a guarantee auction. Feedback or feedback is a process to measure, assess whether the results of this process are in accordance or not with the standards/targets to be achieved by the company. If optimal conditions have been reached (NPF position $<5 \%$ ), feedback will provide input for improvement of inputs or processes for improvement in the future. 
Table 4: Application of the Islamic Humanity Concept in Solving Problematic Financing at BSM Indonesia

\begin{tabular}{|l|l|l|}
\hline No & \multicolumn{1}{|c|}{ Approach } & \multicolumn{1}{c|}{ Information } \\
\hline 1 & $\begin{array}{l}\text { The concept of } \\
\text { hospitality }\end{array}$ & $\begin{array}{l}\text { Billing is done by way of friendship, } \\
\text { and customers are considered as } \\
\text { families who need solutions to the } \\
\text { problems encountered. }\end{array}$ \\
\hline 2 & $\begin{array}{l}\text { Family } \\
\text { communication } \\
\text { and } \\
\text { deliberation }\end{array}$ & $\begin{array}{l}\text { After the friendly meeting, the } \\
\text { bank communicates with cas a } \\
\text { family, so Customers will be more } \\
\text { cooperative and open to finding } \\
\text { solutions. }\end{array}$ \\
\hline 3 & $\begin{array}{l}\text { Respect } \\
\text { People }\end{array}$ & $\begin{array}{l}\text { The concept of humanizing } \\
\text { humans. Problematic customers } \\
\text { continue to be treated well and } \\
\text { humanely. }\end{array}$ \\
\hline 4 & $\begin{array}{l}\text { Patience and } \\
\text { Empathy }\end{array}$ & $\begin{array}{l}\text { An attitude to try to understand the } \\
\text { problems faced by customers, this } \\
\text { attitude of empathy is very closely } \\
\text { related to the concept of friendship } \\
\text { and family communication and } \\
\text { respect for people. }\end{array}$ \\
\hline 5 & $\begin{array}{l}\text { The Concept of } \\
\text { Justice }\end{array}$ & $\begin{array}{l}\text { Every step taken by the bank will } \\
\text { always pay attention to justice so } \\
\text { that no party is harmed/wronged. }\end{array}$ \\
\hline Ther & $\begin{array}{l}\text { Every time they start their work, } \\
\text { the bank always prays for the } \\
\text { customers to make their business/ } \\
\text { businesses easier. This is believed } \\
\text { to have an extraordinary effect } \\
\text { on the settlement of problematic } \\
\text { financing. }\end{array}$ \\
\hline
\end{tabular}

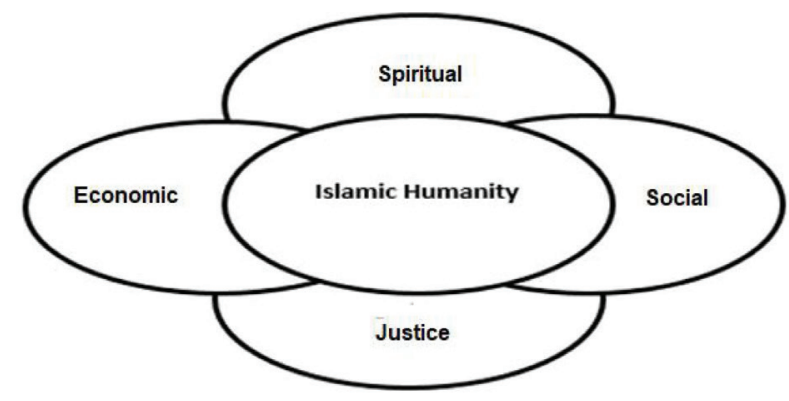

Figure 2: Islamic Humanity Approach for Handling Problematic Financing

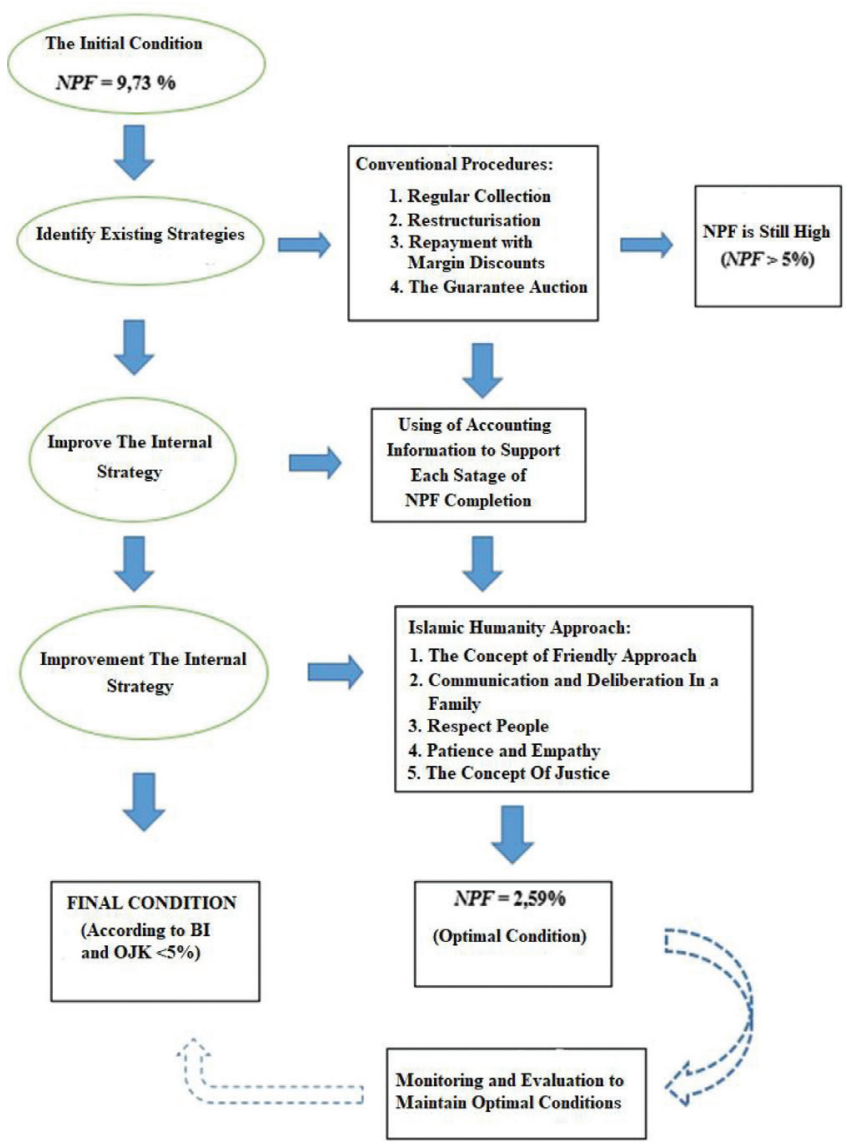

Figure 3: The flow of Handling of non-Performing Financing with Islamic Humanity Approach at BSM Indonesia

Table 5: Progress of Handling of NPF at BSM Indonesia 2016 to 2018

\begin{tabular}{|l|l|c|c|c|}
\hline \multirow{2}{*}{ No } & \multirow{2}{*}{ Month } & \multicolumn{3}{|c|}{$\%$ NPF } \\
\cline { 3 - 5 } & & $\mathbf{2 0 1 6}$ & $\mathbf{2 0 1 7}$ & $\mathbf{2 0 1 8}$ \\
\hline 1 & January & $9,73 \%$ & $2.32 \%$ & $1,36 \%$ \\
\hline 2 & February & $10,36 \%$ & $2.18 \%$ & $1,01 \%$ \\
\hline 3 & March & $8,61 \%$ & $1.87 \%$ & $1,05 \%$ \\
\hline 4 & April & $8,45 \%$ & $1.61 \%$ & $1,07 \%$ \\
\hline 5 & May & $8,04 \%$ & $1.88 \%$ & $1,67 \%$ \\
\hline 6 & June & $7,95 \%$ & $1.60 \%$ & $1,71 \%$ \\
\hline 7 & July & $7,80 \%$ & $1.58 \%$ & $1,92 \%$ \\
\hline 8 & August & $7,41 \%$ & $1.44 \%$ & $2,04 \%$ \\
\hline 9 & September & $6,67 \%$ & $0.83 \%$ & $1,46 \%$ \\
\hline 10 & October & $4,51 \%$ & $0.99 \%$ & $0,74 \%$ \\
\hline 11 & November & $2,56 \%$ & $0.80 \%$ & $0,91 \%$ \\
\hline 12 & December & $2,59 \%$ & $0.88 \%$ & $0,65 \%$ \\
\hline
\end{tabular}

Source: BSM Indonesia 
Handling of non-Performing Financing at BSM Indonesia with the Islamic humanity approach shows a success. This can be seen by the decline in the NPF rate in 2016 from the beginning of the year by $9.73 \%$ and fell to $2.59 \%$ at the end of the year. The progress can be presented in the following table:

This approach's process continues to be improved and developed so that a low NPF number can be maintained. The researcher concludes that the strategy of handling problem financing in Indonesia BSM runs well, effectively, and is consistently carried out and has positive implications. The success of this process continued until 2017 and 2018, as evidenced by the low NPF rate, namely in 2017 amounting to $0.88 \%$ and in 2018 amounting to $0.65 \%$.

\section{Conclusion}

The settlement of problematic financing at BSM Indonesia is based on the stages of the process that have been determined by banking regulations and regulations by government agencies, in this case, DSN MUI, Bank Indonesia, and OJK. Handling problematic financing at BSM Indonesia by adding aspects of spirituality to the sustainability model using the Islamic humanity approach shows success. The implementation of this strategy includes the discipline of billing activities in accordance with banking rules and regulations, followed by improvisation using the spiritual aspect of the Islamic humanity approach. The concept of Islamic humanity carried out in problem-solving activities at BSM Indonesia includes a friendly approach, communication and deliberation in a family, respect people, empathy, the concept of justice, and the concept of prayer.

The billing department must also be familiar with and understand the various kinds of financial and output reports generated by the banking system relating to the billing process and activities. They must be able to read and interpret the financial statements to determine the billing strategy that will be carried out and will later be used to monitor whether the strategy has been successful. Billing activities and handling strategies for problem financing in BSM Indonesia have proven to be effective and has been consistently implemented, this can be seen from the stable NPF rate and decreasing from year to year.

This study's results can provide theoretical implications in terms of new knowledge related to Islamic banking and handling problematic financing, namely by using the Islamic humanity method, which is used as a source for taking policy handling financing problems. This research also gave rise to a new concept of incorporating Islamic humanity in banking activities, as an additional method for handling problem financing. For Islamic banking in Indonesia, the results of this study can provide a new approach that is with Islamic Humanity in terms of handling problematic financing in
Islamic banking in particular and conventional banking in Indonesia.

\section{References}

Abid, L., Ouertani, M. N., \& Zounari-Ghorbel, S. (2014). Macroeconomic and Bank-Specific Determinants of Household's Non-Performing Loans in Tunisia: A Dynamic Panel Data. Procedia Economics and Finance, 13(December 2013), 58-68.

Adeyemi, B. (2011). Bank Failure in Nigeria: A Consequence of Capital Inadequacy, Lack of Transparency and Non-Performing Loans? Banks and Bank Systems, 6(1), 99-109.

Africa, S. N., \& Maesyaroh. (2017). Problematic Financing Analysis and Handling Efforts at PT. SRB Margarizki Bahagia Yogyakarta (Symbolic Interaction Sociological Approach Study). Thesis, Yogyakarta Muhammadiyah University, Indonesia.

Antonio, M. S. (2017). Sharia Bank from Theory to Practice. Jakarta, Indonesia: Gema Insani Press.

Az-Zahrani, M. (2017). History and Development of the Prophetic Hadiths. Jakarta, Indonesia: Darul Haq

Bank Indonesia Regulation Number: 7/2 / PBI / 2005. (2005). Regarding the Asset Quality Assessment for Commercial Banks. Jakarta, Indonesia: Bank Indonesia Regulation.

Bank Indonesia Regulation Number: 9/9 / PBI / 2007. (2007). Concerning Amendments to Bank Indonesia Regulation Number 8/21 / PBI / 2006. Jakarta, Indonesia: Bank Indonesia Regulation.

Bank Indonesia Regulation Number: 10/18 / PBI / 2008. (2008). Regarding Financing Restructuring for Sharia Banks or Sharia Business Units. Jakarta, Indonesia: Bank Indonesia Regulation.

Berger, A. N., \& DeYoung, R. (1997). Problem loans and cost efficiency in commercial banks. Journal of Banking and Finance, 21(6), 849-870. https://doi.org/10.1016/S03784266(97)00003-4

Burton, R. M., Lauridsen, J., \& Obel, B. (2002). Return on Assets Loss from Situational and Contingency Misfits. Management Science, 48(11), 1461-1485.

Dao, B. T. T., \& Nguyen, D. P. (2020). Determinants of Profitability in Commercial Banks in Vietnam, Malaysia and Thailand. Journal of Asian Finance, Economics and Business, 7(4),133143. https://doi.org/10.13106/jafeb.2020.vol7.no4.133

Eko, G. S. (2010). Metamorphosis of social and environmental accounting: Constructing Spiritual Dimensions of Sustainability Accounting. Inauguration Speech of the Professor of the Faculty of Economics and Accounting, Brawijaya University, Malang, Indonesia.

Espinoza, R., \& Prasad, A. (2010). Non-performing loans in the GCC Banking System and their Macroeconomic Effects. IMF Working Papers, 2010/224. https://doi. org/10.5089/9781455208890.001 
Fatchan. (2011). Qualitative research Methods. Surabaya, Indonesia: Jenggala Pustaka Utama.

Fauzi, Y. 2012. Interpret Work. Matter I. Bandung, Indonesia: PT. Mizan Pustaka

Financial Service Authority. (2005). Sharia Banking Statistics. Retrieved from www.ojk.go.id

Firdaus, R., \& Ariyanti, M. (2008). Commercial Bank Credit Management: Theory, Policy Issues, and Applications. Bandung, Indonesia: Alfabeta.

Firmansyah, I. (2014). Determinant of Non-Performing Loan: The Case of Islamic Bank in Indonesia. Bulletin of Monetary Economics and Banking, 17(2), 241-258. https://doi. org/10.21098/bemp.v17i2.51

Modigliani, F., \& Miller, M. H. (1958). The Cost of Capital, Corporation Finance and Theory of Investment. The American Economic Review, 48(3), 261-297.

Havidz, S. A. H., \& Setiawan, C. (2015). Bank Efficiency and NonPerforming Financing (NPF) in the Indonesian Islamic Banks. Asian Journal of Economic Modelling, 3(3), 61-79. http://www. aessweb.com/pdf-files/AJEm- 2015-3(3)-61-79.pdf

Haneef, S., Rana, M. A., \& Karim, Y. (2012). Impact of Risk Management on Non-Performing Loans and Profitability of Banking Sector of Pakistan Hailey College of Commerce University of the Punjab Hafiz Muhammad Ishaq Federal Urdu University of Arts, Science and Technology. International Journal of Business and Social Science, 3(7), 307-315.

Harianto, S. (2017). Financial Ratios and The Effects on Profitability at Islamic People's Financing Banks. Essence: Journal of Business and Management, 7(1), 41-48. https://doi. org/10.15408/ess. v7i1.4076

Hosen, M. N., \& Muhari, S. (2019). Non-Performing Financing of Islamic Rural Bank Industry in Indonesia. Banks and Bank Systems, 14(1), 20-28. https://doi.org/10.21511/ bbs.14(1).2019.03

Ibrahim, A., \& Rahmati, A. (2012). Solutive analysis of problem funding Settlement at Sharia Banks: Study on Financing Products at Bank Muamalat Indonesia Banda Aceh. Journal of Islamic Economics and Business Studies-Iqtishadia, 10(1), 2502-3993.

Jureid. (2016) Islamic Bank Risk Management (Problem Funding Handling for Financing Products at PT. Bank Muamalat Panyabungan Sub-Branch). Analytica Islamica, 5(1), 81-107.

Jusni, P. B. T., Aswan, A., \& Syamsuddin, A. R. (2019). Financing Profitability Optimization: Case Study on Sharia Business Unit of Regional Development Banks in Indonesia. Banks and Bank Systems, 14(1), 1-10. https://doi.org/10.21511/ bbs.14(1).2019.01

Karim, A. A. (2010). Islamic Bank Fiqh and Financial Analysis (4 $4^{\text {th }}$ ed.). Jakarta, Indonesia: PT Rajagrafindo Persada

Kencana, S. S., Hariyani, H., \& Panjaitan, F. (2016). Analysis of the Effect of Debtor Characteristics Based on Principle 5c on Non-Performing Loans (Case Study in Mega Central Finance,
Bangka Branch). Jurnal Progresif Manajemen Bisnis, 14(2), 46-58. http://dx.doi.org/10.15408/ess.v7i1.4076

Kuntowijoyo. (1993). Islamic Paradigm: Interpretation for Action. Bandung, Indonesia: Mizan Law no. 10 of 1998 concerning Banking

Louzis, D. P., Vouldis, A. T., \& Metaxas, V. L. (2012). Macroeconomic and Bank-Specific Determinants of NonPerforming Loans in Greece: A Comparative Study of Mortgage, Business and Consumer Loan Portfolios. Journal of Banking and Finance, 36(4), 1012-1027. https://doi. org/10.1016/j.jbankfin.2011.10.012

Maarif, A. S. (2009). Islam in the Frame of Indonesianity and Humanity: A Reflection of History. Bandung, Indonesia: PT. Mizan Reader

Masruki, R., Ibrahim, N., Osman, E., \& Wahab, H. A. (2011). Financial Performance of Malaysian founder Islamic Banks versus Conventional Banks. Journal of Business and Policy Research, 6(2), 67-79.

Messai, A. S., \& Jouini, F. (2013). Micro and Macro Determinants of Non-Performing Loans. International Journal of Economics and Financial Issues, 3(4), 852-860.

Miles, M. B., \& Huberman, M. (2014). Qualitative Data Analysis. Jakarta, Indonesia: University of Indonesia.

Muhammad, H., Rehman, A. U., \& Waqas, M. (2016). The Relationship between Working Capital Management and Profitability: A Case Study of Tobacco Industry of Pakistan. Journal of Asian Finance, Economics and Business, 3(2), 1320. https://doi.org/10.13106/jafeb.2016.vol3.no2.13.

Nurjanah., \& Hilyatin, D. L. (2016). The strategy of Saving Problem Funding in Murabahah Financing at Bank Syariah Mandiri Purwokerto Branch. Journal of Islamic Economics / Islamic Economic Journal (El Jizya), Vol. 4.

Poetry, Z. D., \& Sanrego, Y. D. (2014). Pengaruh Variabel Makro dan Mikro terhadap NPL Perbankan Konvensional dan NPF Perbankan Syariah. Tazkia Islamic Finance and Business Review, 6(2). http://dx.doi.org/10.30993/tifbr. v6i2.53

Qayyum, N., \& Noreen, U. (2019). Impact of Capital Structure on Profitability: A Comparative Study of Islamic and Conventional Banks of Pakistan. Journal of Asian Finance, Economics and Business, 6(4), 65-74. https://doi.org/10.13106/jafeb.2019. vol6.no4.65

Robingun. (2016). Values of Humanity in the Education of the Prophet Muhammad (Interpretation-Based Studies - Hadith). Dissertation. UIN Sunan Kalijaga, Indonesia.

Saba, I., Kouser, R., \& Azeem, M. (2012). Determinants of NonPerforming Loans: Case of US Banking Sector. The Romanian Economic Journal, 44(6), 125-136.

Samad, A., \& Hassan, M. K. (1999). The Performance of Malaysian Islamic Bank During 1984-1997: An Exploratory Study. International Journal of Islamic Financial Services, 1(3), 1-14. Retrieved from https://papers.ssrn. com/sol3/papers. cfm?abstract_id=3263331 
Selling, T. I., \& Stickney, C. P. (1989). The Effects of Business Environment and Strategy on a Firm's Rate of Return on Assets. Financial Analysts Journal, 45(1), 43-68. http://www. jstor.org/stable/4479186

Shariati, A. (1992). Humanism between Islam and Western Schools. Afif Muhammad's translation. Bandung, Indonesia: Hidayah Library.

Siswanto, S. (2009). Troubled Credit Settlement at People's Credit Banks. Retrieved from: lib.ui.ac.id

Sugiyono. (2014). Understanding Qualitative Research. Bandung, Indonesia: Alfabeta Publisher.

Tangngisalu, J., Hasanuddin, R., Hala, Y., Nurlina, N., \& Syahrul, S. (2020). Effect of CAR and NPL on ROA: Empirical Study in Indonesia Banks. Journal of Asian Finance, Economics and
Business, 7(6), 9-18. https://doi.org/10.13106/jafeb.2020.vol7. no6.009

Waemustafa, W., \& Sukri, S. (2015). Bank Specific and Macroeconomics Dynamic Determinants of Credit Risk in Islamic Banks and Conventional Banks. International Journal of Economics and Financial Issues, 5(2), 476-481. Retrieved from http://www.econjournals. com/index.php/ijefi/article/ view/1105

Yanikkaya, H., Gümüş, N., \& Pabuçcu, Y. U. (2018). How Profitability Differs between Conventional and Islamic Banks: A Dynamic Panel Data Approach. Pacific Basin Finance Journal 48(February), 99-111.

Zaini, A. B., Karim, M., Chan, S.-G., \& Hassan, S. (2010). Bank Efficiency and Non-Performing Loans: Evidence from Malaysia and Singapore. Prague Economic Papers, 19(2), 118132. https://doi. org/10.18267/j.pep.367 